A Survey of recent Japanese research on dormancy in Potato tubers

by

J. BRUINSMA

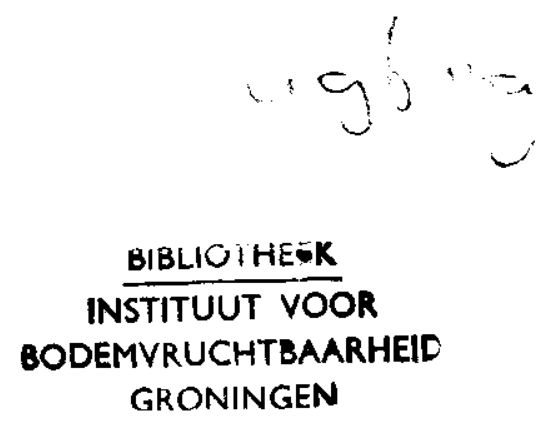

Publication No. 15 of the Plant Physiological Research Centre Wageningen, Netherlands Reprint Eur. Pot. J., Vol. 5 (1962) No. 3 (Sept.) 


\title{
A SURVEY OF RECENT JAPANESE RESEARCH ON DORMANCY IN POTATO TUBERS
}

\author{
J. BRUINSMA
}

Plant Physiological Research Centre, Wageningen, Netherlands

Summary, Zusammenfassung, Résumé, p. 202

\section{INTRODUCTION}

At the First Triennial Conference of the European Association for Potato Research BURTON (1960) surveyed the present status of European and American research on the physiology of the potato. On the question of dormancy and sprout growth he had to conclude that "investigations have hitherto failed to provide any consistent explanation of these phenomena". Far from intending to provide any such explanation, the author considers it useful to review some recent but rather difficult accessible results of research on the same topic in Japan and to present a scheme in which these results are interrelated into another working hypothesis for further investigations.

About the middle of the past decade the Japanese physiologist T. TAGAWA of the Agricultural Faculty of the Hokkaido University, Sapporo, turned his attention to the biochemical background of dormancy in the potato tuber. Together with his co-workers, Y. OKazawa and Y. NishiYama, he developed the investigations along two lines, viz. the various effects of natural substances stimulating and inhibiting growth, and the nature of the respiratory enzyme systems in dormant and sprouting tubers. Recently connections have been found between these two lines of research, and this enables a tentative over-all picture to be drawn. Although respiration studies began earlier, for the sake of convenience those dealing with growth-regulating substances will be dealt with first.

\section{THE INFLUENCE OF GROWTH-REGULATING SUBSTANCES ON TUBERIZATION AND SPROUTING}

Investigations into the part played by growth regulators in the dormancy of potato tubers started from the results of European research. In 1956, TAGAWA and NI-

Received for publication 1st February, 1962. 
SHIYAMA determined the glutathione contents in various parts of tubers from two groups of plants, one of which was sprayed with a $0,2 \%$ solution of maleic hydrazide (MH) three weeks before harvesting. The tubers were stored at room temperature in the dark. At seven dates, from 10th September to 7th February, samples were taken in order to determine the oxidized and reduced glutathione. Both forms of glutathione tended to increase at the end of the dormant period, especially in cortex tissue with an apical bud. This tendency was less pronounced in tubers from $\mathrm{MH}$-treated plants. Since there was a similar increase in glutathione content when the tubers were treated with ethylene chlorohydrin, which accelerates sprouting, the glutathione content of the apical bud in particular is believed to be a factor in the termination of dormancy.

In the same year another paper was published on a subject suggested by European research. TAgawa and OKazawa (1956b), following Hemberg's techniques (see HEMBERG, 1961), extracted from the peel of dormant potato tubers an acid-resistant substance which could be absorbed on active charcoal. The substance reduced the growth-promoting effect of 0,1 p.p.m. of 3-indoleacetic acid (IAA) in the Avenatest. The moisture uptake by parenchymous tuber disks could be stimulated by 1 p.p.m. of 1-naphthylacetic acid (NAA); this auxin-induced moisture uptake was also reversed by the extracted substance. Experiments on the moisture permeability of tuber disks $10 \mathrm{~mm}$ in diameter and $0,5 \mathrm{~mm}$ thick in hypotonic and hypertonic sucrose solutions (without auxin) showed that the inhibiting substance lowered the moisture permeability of the parenchymous cells. The authors suggested that this property of the substance might account for the anti-auxin effect on the one hand and its rôle in dormancy on the other.

The next two studies in the field of growth regulators, both undertaken by OKAZAWA, were concerned with the occurrence of natural gibberellins in the potato plant, especially in the tuber. According to OKAZAWA (1959) ethanol extracts from various parts of the potato plant contained substances which could be purified by paper chromatography and behaved like gibberellins in the wheat-leaf test, the ultra-violet ray test and when treated with acid and alkali. The relative concentration of these substances in the various parts of the plant was tuber sprouts $>$ stem tip $>$ tuber $>$ middle part of the stem $>$ foliage. These experiments also established the presence of natural substances that counteract the gibberellin effect.

It was also demonstrated that tuber formation under short-day conditions could be suppressed by treating the plants with 100 p.p.m. of gibberellin.

Continuing along this line, OKAZAWA (1960) found that under conditions favourable to tuber formation, e.g. low temperature $\left(13^{\circ} \mathrm{C}\right)$ and short day-length $(8 \mathrm{hrs}$ of light per day), there was a considerable decrease in the gibberellin content of leaf blades. This was determined by measuring the activity of chromatographically purified extracts in the wheat-leaf test. Therefore, apart from the presence of a tuberization stimulus, as demonstrated by CHAPMAN (1958), cessation of stolon elongation and induction of tuber formation seems to be connected with a decline in the gibberellin content of the plant.

In senile tubers which lost their sprouting capacity the gibberellin content was 
found to be low; exposure of these tubers to diffuse daylight for about a month led to a very marked increase in gibberellin content as well as a recovery of sprouting capacity.

This finding is in accordance with the results of an experiment undertaken by RAPPAPORT and SMITH (1962) in which the gibberellin content of potato tubers turned out to be low in the dormant state and to increase more than 30 -fold when sprouting.

Summarizing the results of these investigations into the part played by growth regulators in tuberization and sprouting, it can be stated that it seems likely that antagonistic equilibria occur between growth-promoting and inhibiting substances. In these equilibria gibberellin-like compounds promote stolon and sprout growth.

\section{RESPIRATORY PATHWAYS IN DORMANT AND SPROUTING TUBERS}

In the dormant potato tuber respiration proceeds at a low rate in order to provide the energy needed to maintain the differences in concentrations and potentials which are essential to the biological structure. But at the end of the dormant period the respiration rate increases because growth and differentiation of the sprouts require large supplies of energy. It is a question whether the increased respiration rate is the result of an enlargement or intensification of the respiratory system that was already producing energy during dormancy or whether, when cell division and elongation is resumed, new energy-producing systems arise in addition to or instead of those active during dormancy.

The respiratory systems known from plant tissues have been described by BEEVERS (1961) and are summarized in TABLE 1. In alle four systems some substrate is oxidized by a dehydrogenase with simultaneous reduction of DPN or TPN. These codehydrogenases are again oxidized by other intermediates and ultimately a terminal oxidase reduces molecular oxygen to water or hydrogen peroxide. Via the links in this oxjdation-reduction chain the energy difference between the substrate and its oxidation product is divided piecemeal and transferred to phosphate bonds. This oxidative phosphorylation provides the cell with the energy required for maintaining and extending its structures.

The four systems, named after their terminal oxidases, can be distinguished by differences in their sensitivity to inhibitors and their affinity to oxygen, as is shown in TABLE 2. The iron-containing cytochromes, and phenol and ascorbate oxidases with copper as an active group, are inhibited by such heavy metal poisons as cyanide and carbon monoxide. The carbon monoxide inhibition of cytochrome oxidase can be removed by illumination. The flavoprotein glycollate oxidase is insensitive to these inhibitors. Antimycin A specifically inhibits the electron transport via the cytochrome oxidase pathway, salicylaldoxime that via the phenol oxidase system, while acriflavine specifically blocks the glycollate oxidase path. A specific inhibitor for the ascorbate oxidase system is still unknown. The latter, together with the glycollate oxidase path, has a fairly low affinity to oxygen, so that their rate of oxygen uptake is low when the oxygen tension is reduced to a few per cent. 
TABle - TABELlE - TABleAU 1. Oxidase systems - Oxydasesysteme - systèmes à oxydases (data from - Angaben von - donnés empruntés à: H. BEEVERS, Respiratory metabolism in plants, 196I)

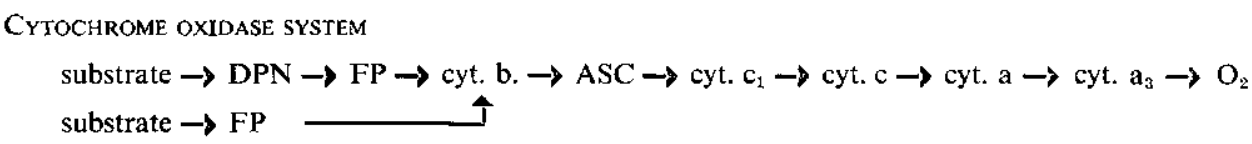

Phenol oXidase SYSTEM

substrate $\rightarrow$ TPN

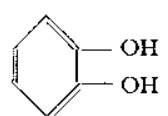

$\checkmark$<smiles>O=C1C=CC=CC1=O</smiles>

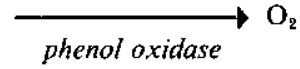

\section{ASCORBATE OXIDASE SYSTEM}

substrate $\rightarrow$ TPN $\rightarrow$ glutathione $\rightarrow$ ascorbic acid $\rightarrow \mathrm{O}_{2}$

\section{GLyCOLIC ACID OXIDASE SYSTEM}

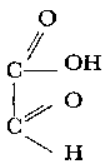

substrate $\rightarrow$ DPN glyoxylate reductase
11<smiles>O=C(O)CO</smiles>

glycollate oxidase

\section{$\mathrm{O}_{2}$}




\section{A SURVEY OF RECENT JAPANESE RESEARCH ON DORMANCY IN POTATO TUBERS}

In their first enzymological investigation TAGAWA and OKAZAWA (1955a) followed the occurrence of phosphorylase, the starch-synthesizing P-enzyme, throughout the life-cycle of the potato plant. They observed an increasing activity in the growing tuber which was proportional to the starch content and reached its optimum at harvest-time. During dormancy phosphorylase activity gradually declined, but again rose temporarily in the cortex and the apical bud at the end of the dormant period.

This observation led to a closer enzymological analysis of the termination of dormancy. TAGAWA and OKAZAWA (1955b), confirming their earlier findings on phosphorylase activity, described a striking rise in amylase activity at the commencement of sprouting. Hence the starch breakdown which accompanies the increasing respiration rate is hydrolytic rather than phosphorylytic. At the same time there was a gradual decline in the ascorbic acid content.

In an attempt to locate the respiratory activities in the various parts of the tuber during the storage period at room temperature, TAGAWA and OKAZAWA (1956a) determined the oxygen uptake of different parts of tubers by means of a direct Warburg technique. During dormancy the rate of respiration gradually slowed down, but at the end of the dormant period it rose rapidly, this occurring in the terminal bud only. After the tubers had been treated with MH, NAA or Bervitan $\mathrm{K}$ there was no such rise, whereas after cold storage the respiration rate of the whole tuber was increased on the termination of dormancy. It was concluded that the apical bud plays a special part in dormancy.

The effects of inhibitors on the respiration rates of cortex tissue with and without a bud, in the dormant and sprouting stages, were investigated by determinations with the use of the Warburg apparatus (TAGAWA and NishIYAMA, 1958). It was found that $10^{-3} \mathrm{M}$ of cyanide always had an inhibiting effect, but to a higher degree after than during dormancy. This need not imply that a new, more cyanide-sensitive system arose at the end of dormancy, since during this stage cyanide could have been diluted over non-active enzyme. More convincing evidence of the emergence of a new respiratory pathway was provided by experiments with Dieca (diethyl dithiocarbamate), which showed the reverse effect: $10^{-3} \mathrm{M}$ of Dieca severely inhibited oxygen uptake during dormancy but hardly at all during the sprouting stage. This led to the suggestion that the phenol oxidase path might be the main system for electron transport during dormancy only. In accordance with the results of experiments undertaken by TODD (1953), the authors found a gradually declining phenol oxidase (=- tyrosinase) activity in the supernatant liquid after centrifugation of ground tuber tissue. After the tubers had been treated with Bervitan $K$ this activity was maintained for a longer period. Since IAA was found to be rapidly inactivated by phenol oxidase in the presence of catechol and air, the authors suggested that the phenol oxidase pathway might affect dormancy by regulating the auxin levels.

More specific inhibitors were used in the later experiments (NISHIYAMA and TAGAWA, 1959,1960 ). Measurements of the oxygen uptake of tissue disks $8 \mathrm{~mm}$ in diameter and $1 \mathrm{~mm}$ thick in $1 / 15 \mathrm{M}$ of phosphate buffer and at $25^{\circ} \mathrm{C}$ showed that $10^{-3} \mathrm{M}$ of salicylaldoxime inhibited respiration from the commencement of dormancy until break- 
ing thereof with gibberellin or thiourea. This indicates that a considerable part of the electron transport occured via the phenol oxidase pathway. Since, however, 1 p.p.m of antimycin $\mathrm{A}$ also inhibited oxygen uptake to about the same extent during both dormancy and sprouting, the cytochrome oxidase system must also have been active in the dormant tuber. That this activity was hardly affected by the termination of the dormant stage was also shown by the unchanged light-reversibility of the inhibition of respiration by $95 \% \mathrm{CO}+5 \% \mathrm{O}_{2}$ (control: $95 \% \mathrm{~N}_{2}+5 \% \mathrm{O}_{2}$ ). The low oxygen tension used in the latter experiments appeared to restrict the respiration rate of disks cut from sprouting tubers, whereas the inhibition by Dieca and salicylaldoxime was found to be reduced in these disks. The phenol oxidase system was therefore probably replaced by some flavoprotein oxidase system of the glycollate oxidase type at the end of dormancy. This could be proved by the much greater inhibition of oxygen uptake after dormancy by $10^{-3} \mathrm{M}$ of acriflavine at $\mathbf{P}_{\mathbf{H}} 6,2$.

Tubers from plants infected with witches' broom virus usually show no dormancy. The respiration of these tubers closely resembled that of sprouting tubers, i.e. it was not very sensitive to Dieca but its rate was greatly reduced both by acriflavine and $5 \%$ of oxygen. The auxin content of these infected tubers was found to be equal to that of healthy ones, but there was a marked increase in their gibberellin content.

The change in relative participation of the various systems in the total oxygen consumption at the end of dormancy reminded the authors of American research on changes in respiratory systems of potato tuber slices after prolonged washing. These washings resulted in the appearance of an enzyme system which was no longer sensitive to $\mathrm{CO}$ but to low $\mathrm{O}_{2}$-tensions instead (LevY and SCHADE, 1948; ThIMANN et al., 1954). NishiYama and TAGaWA did in fact find that when disks cut from dormant tubers were soaked in water for $48 \mathrm{hrs}$ at $13^{\circ} \mathrm{C}$, they became as sensitive to acriflavine and $5 \% \mathrm{O}_{2}$ as fresh disks cut from sprouting tubers. In order to ascertain whether this change in respiratory pathways was due to the removal of some substance, the authors soaked disks in water containing the acidic inhibitor extracted from dormant tuber peel and purified by paper chromatography. Respiration of these disks was found to be as little sensitive to acriflavine as fresh disks cut from dormant tubers, and only slightly more sensitive to a lowered oxygen tension; apparently they remained in the dormant stage. The addition of 1,10 and 100 p.p.m. of gibberellin to the inhibitor containing soaking solution gradually eliminated the effect of the inhibitor, the respiration of the disks becoming increasingly sensitive to acriflavine and $5 \% \mathrm{O}_{2}$. In this inhibitor-gibberellin antagonism, 10 and 100 p.p.m. of gibberellin was replaced by $10^{-3} \mathrm{M}$ and $5.10^{-3} \mathrm{M}$ of glutathione respectively.

It was also found possible to accelerate sprouting of apical buds on cylinders of dormant tuber tissue by washing the cylinders for 4 days with fresh water of $13^{\circ} \mathrm{C}$.

\section{INTERPRETATION OF THE RESULTS}

It may be concluded from the above data that the transition from the dormant to the sprouting stage is accompanied by a change in participation of the respiratory path- 


\section{A SURVEY OF RECENT JAPANESE RESEARCH ON DORMANCY IN POTATO TUBERS}

ways in the total oxygen uptake of tuber disks. Although the respiration rate of the disks greatly outmeasures that of intact tubers, it is improbable that the changes found in disk respiration would not reflect corresponding changes occurring in the respiratory apparatus of intact tubers at termination of dormancy. The phenol oxidase system diminishes, but on the other hand a large amount of some flavoprotein system arises, which we provisionally term the glycollate oxidase system. The cytochrome oxidase system seems to be only slightly affected. These changes appear to be regulated by an antagonism between the acidic inhibitor on the one hand and gibberellin and glutathione at the other. The ratio between growth-inhibiting and stimulating substances determines in some way the relative activities of the phenol and glycollate oxidase systems. An attempt to express this schematically is made in the FIGURE. A high relative activity of the phenol oxidase pathway maintains dormancy, possibly also by inacti-

FIGURE. Scheme of interrelations between growth-regulating substances and respiratory enzyme systems

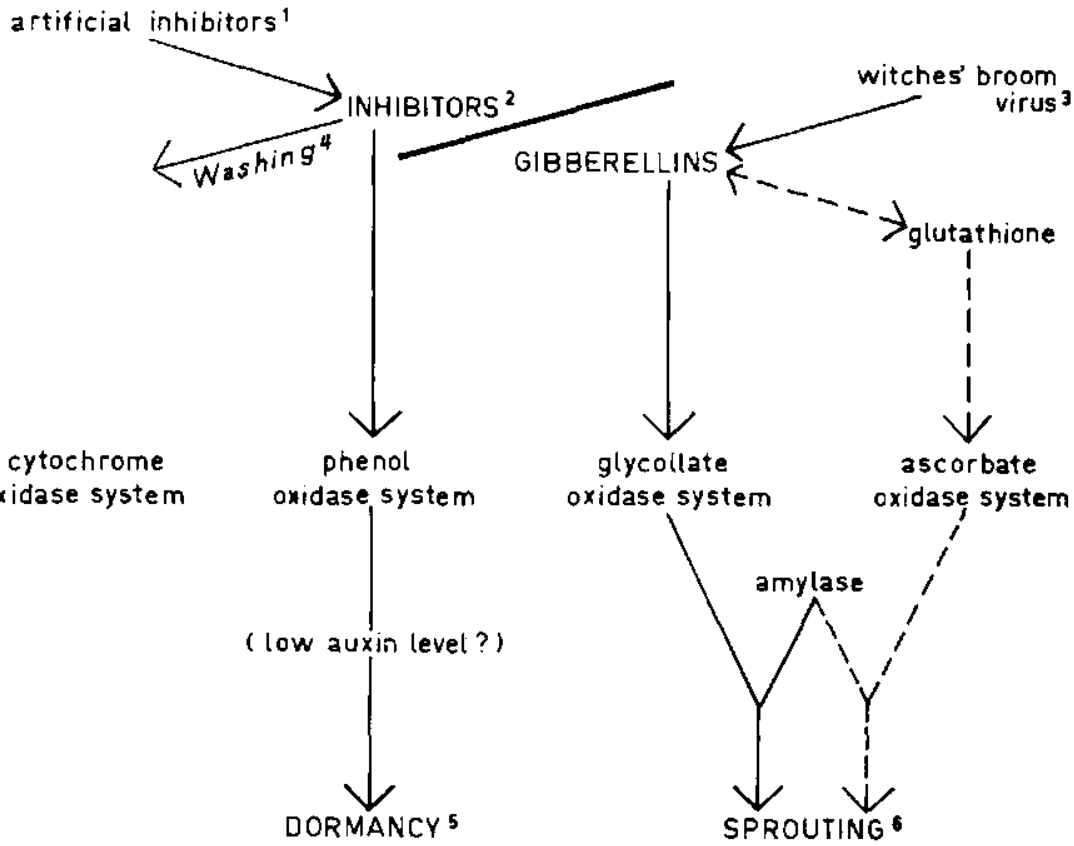

' Künstliche Hemmstoffe - substances artificielles inhibitrices.

${ }^{3}$ Hemmstoffe - substances inhibitrices.

"Hexenbesen-Virus - virus du balai de sorcière.

Auswaschung - lessivage.

- Keimruhe - dormance.

- Keimung - germination.

ABBILDUNG. Schema der Wechselbeziehungen zwischen wachstumsregulierenden Stoffen und Atmungsenzymsystemen

FiguRE. Schéma des rapports entre les substances régulatrices de croissance et les systèmes enzymatiques respiratoires

Eur. Pot. J., Vol. 5 (1962) No. 3 (September) 
vating growth substances in turn, which might indicate the presence of some coupling mechanism. Sprouting is accompanied by a high activity of the glycollate oxidase system, and is made possible by an increased rate of starch hydrolysis since amylase activity increases. It is interesting in this respect that the activity of $\alpha$-amylase is repressed by the inhibitor isolated from dormant tubers by HEMBERG and LARSSON (1961).

The inhibitor/gibberellin ratio can be influenced by various artificial compounds, some of which are known to be growth promoting or inhibiting substances, e.g. MH. Infection with witches' broom virus shifts the ratio in favour of gibberellin. Whether glutathione has this effect is uncertain. Possibly its own concentration is controlled by the inhibitor/gibberellin ratio and influences sprouting directly by supplying an eventual ascorbate oxidase system with intermediates. The absence of a specific inhibitor makes it difficult to assess the part played by this ascorbate oxidase system in the total oxygen consumption during and after dormancy. MAPSON and BURTON (1962) were unable to detect the enzyme ascorbate oxidase in potato tuber tissue. The authors, however, investigated dormant tubers freshly picked from the field only. According to TAGAWA and OKAZAWA (1955b) there is no rise in ascorbic acid content at the commencement of sprouting.

The scheme, tentative and full of queries as it may be, is presented as an interpretative summary of the results obtained by the Japanese investigators. It is hoped that these results may prove useful to European research on dormancy of the potato tuber.

\section{ACKNOWLEDGEMENTS}

The author is greatly indebted to Ir. A. J. REESTMAN of the Research and Advisory Institute for Field Crop and Grassland Husbandry (P.A.W.), Wageningen, Netherlands, for having drawn his attention to the subject and for placing the literature at his disposal. The translations by Dr. H. KuBo, Agricultural Chemical Inspections Station, Tokyo, Japan, are greatly appreciated.

\section{SUMM A R Y}

A review is given of recent Japanese research on the physiology and biochemistry of dormancy in the potato tuber. The influence of natural growth inhibiting and stimulating compounds on tuberization and sprouting is discussed. The ratio be- tween these growth-regulating substances probably controls the shift in relative activity of different respiratory enzyme systems occurring on the termination of dormancy.

\section{ZUSAMMENFASSUNG}

\section{NEUE JAPANISCHE LITERATUR ÜBER DIE KEIMRUHE DER KARTOFFEL}

Es wird berichtet über neue physiologische und biochemische, in Japan durchgeführte Untersuchungen in bezug auf die Keimruhe der Kartoffelknolle. Die Einflüsse, welche natürlich vorkommende wachstumshemmende und -fördernde Stoffe auf die Knollenbildung und die Kei- mung ausüben, werden behandelt. Das Verhältnis zwischen diesen Wachstumsregulatoren beeinflusst die Veränderungen der relativen Aktivität der verschiedenen Atmungsenzymsysteme die bei der Beendung der Keimruhe auftreten.

Eur. Pot. J., Vol. 5 (1962) No. 3 (September) 


\title{
A SURVEY OF RECENT JAPANESE RESEARCH ON DORMANCY IN POTATO TUBERS
}

\author{
RÉS U MÉ \\ APERÇU DES RECHERCHES JAPONAISES ACTUELLES SUR LA DORMANCE \\ DE LA POMME DE TERRE
}

L'auteur nous renseigne sur les recherches physiologiques et biochimiques sur la dormance de la pomme de terre récemment effectuées au Japon. Il traite l'influence des substances naturelles inhibitrices ou stimulatrices de croissance sur la formation des tubercules et la germination. La proportion de substances de ces deux groupes influence la modification des rapports d'activités des systèmes respiratoires à la fin de la dor. mance.

\section{JAPANESE REFERENCES (chronological)}

TAGAWA, T., and Y. OKazAWA (1955a): Physiological and morphological studies on potato plants. Part 17. On the variation of phosphorylase activity of potato plants throughout an entire lifecycle. Paper on the 61st anniversary of Prof. Tochinai and FukuZi.

(1955b): The same. Part 18. On the influences of nature and of age of seed tubers on some physiological behaviours at the time of sprouting of the tubers. Proc. Crop Sci. Soc. Japan. 23, p. 249.

- (1956a): The same. Part 19. Studies on the localization of the respiratory activities in potato tubers. Proc. Crop Sci. Soc. Japan. 24, p. 193.

—_ (1956b): The same. Part 21. Especially on the sprout inhibiting substances in resting potato tubers. Proc. Crop Sci. Soc. Japan. 25, p. 101.

Tagawa, T., and Y. Nishiyama (1956): The same. Part 20. On the variation in the glutathione contents in the potato tubers during the storage period. Proc. Crop Sci. Soc. Japan. 25 , p. 99.

(1958): On the relativity between copper enzyme and the dormancy of the potato tubers. Proc. Crop Sci. Soc. Japan. 27, p. 91.

OKAZAWA, Y. (1959): Studies on the occurrence of natural gibberellin and its effect on the tuber formation of potato plants. Proc. Crop Sci. Soc. Japan. 28, p. 129.

NishiYama, Y., and T. TAGaWA (1959): On the changes of the terminal oxidase systems with special reference to the dormancy of potato tubers. Proc. Crop Sci. Soc. Japan. 28, p. 134.

OKazawa, Y. (1960): Studies on the relation between the tuber formation of potato and its natural gibberellin content. Proc. Crop Sci. Soc. Japan. 29, p. 121.

NishiYAmA, Y., and T. TAGAWA (1960): On the relation between the change of respiratory system and the dormancy of potato tubers. Proc. Crop Sci. Soc. Japan. 29, p. 182.

\section{OTHER REFERENCES}

Beevers, H. (1961): Respiratory metabolism in plants. Row, Peterson \& Cy, Evanston/White Plains.

Burton, W. G. (1960): The physiology of the potato: problems and present status. Proc. 1st Triennial Conf. Eur. Ass. Potato Res. p. 79.

Chapman, H. W. (1958): Tuberization in the potato plant. Physiol. Plantar. 11, p. 215.

Hemberg, T. (1961): Biogenous inhibitors. Encyclopedia Plant Physiol. 14, p. 1162.

and I. LARSSON (1961): The inhibitor B-complex from resting potato tubers as an inhibitor of $\alpha$-amylase. Physiol. Plantar. 14, p. 861 .

LeVY, H., and A. L. SCHAde (1948): Studies in respiration of the white potato. II. Terminal oxidase system of potato tuber respiration. Arch. Biochem. Biophys. 19, p. 273.

Mapson, L. W. and W. G. BuRton (1962): The terminal oxidases of the potato tuber. Biochem. $J$. 82, p. 19.

RAPPAPORT, L., and O. E. SMITH (1962): Gibberellins in the rest period of the potato tuber. In: Eigenschaften und Wirkungen der Gibberelline. Springer Verlag, Berlin/Göttingen/Heidelberg, p. 37.

ThimanN, K. V., C. S. Yocum and D. P. HacketT (1954): Terminal oxidases and growth in plant tissues. III. Terminal oxidation in potato tuber tissue. Arch. Biochem. Biophys, 53, p. 239.

ToDD, G. W. (1953): Enzyme studies on dormant and active potato tubers. Physiol. Plantar. 6, p. 169.

Eur. Pot. J., Vol. 5 (1962) No. 3 (September) 
